\title{
МЕДІАЛІНГВІСТИКА
}

Visn. Lviv. Univ., Ser. Zhurn. 2020: 48; 143-152 • DOI: http://dx.doi.org/10.30970/vjo.2020.48.10554

УДК 070.4+070.654.197

\section{СТИЛІСТИЧНІ СИНОНІМИ В ТЕЛЕВІЗІЙНОМУ МОВЛЕННІ НАЖИВО}

\author{
Анатолій Капелюшний \\ Львівський національний університет імені Івана Франка \\ вул. Генерала Чупринки, 49, 79044, Львів, Украӥна \\ e-mail: journft@franko.lviv.ua \\ https://orcid.org/0000-0001-8998-7857
}

У статті проаналізовано стилістичні синоніми в телевізійному мовленні наживо. Особливу увагу звернено на вживання одних слів із синонімічного ряду замість інших без урахування відтінків у значенні й в емоційному чи стилістичному забарвленні, на розбіжності у значенні й в експресивному і стилістичному забарвленні, які спричиняють різну сполучуваність синонімів, на помилки в мовленні телевізійних журналістів, пов'язані з недодержанням мовностилістичних норм, на способи уникнення цих помилок, на вироблення відповідних рекомендацій тележурналістам.

Ключові слова: телебачення, прямий ефір, тележурналіст, мовлення телевізійних журналістів, стилістичні синоніми, сполучуваність синонімів.

Постановка проблеми. Використання всього лексичного багатства української мови під час мовлення в прямому ефірі, а не обмеженість лексикону телевізійних «персонажів» кількома десятками модних слів. Таке просте й водночас поки що недосяжне завдання постає перед сучасними телевізійниками із запровадженням мовних квот в ефірі. Тому особливо актуальним стало дослідження деяких аспектів згаданої проблеми, а також вироблення певних рекомендацій для журналістів-практиків. Предметом наших досліджень стали саме деякі аспекти використання лексичної синонімії в журналістському мовленні в прямому ефірі.

Аналіз останніх досліджень та публікацій. Проблеми використання в мас-медіа лексичної синонімії докладно розглянуті в низці досліджень українських учених. Загалом, за правильним зауваженням Г. Й. Волкотруб, «наявність синонімів допомагає урізноманітнити мовлення, уникнути повторів слів, найточніше висловити думки і почуття» ${ }^{1}$. При цьому варто підкреслити саме те, що в стилістиці базовим є прагнення застосувати в конкретному тексті можливості лексичної синонімії. На

\footnotetext{
${ }^{1}$ Волкотруб, Г. Й. (2009), Практична стилістика украӥнської мови: Навчальний посібник, Підручники і посібники, Тернопіль, с. 60.
}

(c) Капелюшний А., 2020 
цьому наголошує й О. Д. Пономарів: «Для стилістики важлива не більша чи менша близькість словникових значень двох чи кількох слів, а те, якими словами можна відтворити певне поняття в певному контексті»². Треба приділити особливу увагу тому, що «за наявності різних емоційно-експресивних відтінків у публіцистичних текстах переважають оцінні моменти використання синонімії». Дається взнаки той негативний чинник, що «упродовж сторіч наша мова захаращувалася калькованими покручами, накинутими невластивими їй формами» ${ }^{4}$. Майже всі висновки, яких доходять відомі українські мовознавці, не викликають особливих дискусій чи заперечень. Проте $\epsilon$ ціла низка специфічних рис мовлення телевізійних журналістів у прямому ефірі, яким досі не приділено належної уваги. А саме ця специфіка праці в прямому ефірі кардинально позначається на точності й ефективності подання інформації, на правильності мовлення журналістів.

Методологічна основа дослідження. Ми зосереджуємося на спостереженнях за телевізійним мовленням у прямому ефірі впродовж 2018 року. Об’єктом дослідження $є$ мовлення журналістів наживо на телеканалах 1+1, 2+2, СТБ, «UA: Перший» (УТ-1), «UA: Львів» (Льв), «Прямий канал» (Прм), «Еспресо» (Ес), «5-й канал» (5-й), «Інтер» (I), «Перший західний» (П3), «24-й канал» (24), «24-й канал. Львів» (24Л), НТА, ZІК, ТРК «Україна» (У), «Футбол 1» (Ф1), «Футбол 2» (Ф2), НЛО, «Обоз $\mathrm{TV} »$, «112-й канал» (112). Основними методами, використаними в цьому дослідженні, отже, $є$ спостереження за мовленням телевізійних журналістів у прямому ефірі перелічених вище телеканалів, а також зіставляння, порівнювання окремих мовників між собою і теоретичних положень та особливостей їх утілення в практику мовлення різних телевізійних організацій. Широко застосовували ми також загальнонаукові методи аналізу й синтезу, узагальнення окремих емпіричних матеріалів та окремих специфічних рис праці різних мовників у прямому ефірі. Не так часто в цьому дослідженні використано методи аксіоматичний, історичний та деякі інші.

Найбільш характерними $є$ випадки вживання одних слів із синонімічного ряду замість інших без урахування відтінків у значенні й в емоційному чи стилістичному забарвленні: Із приміщення податкової евакуювали близько сотню робітників $(1+1 .-2018 .-10$ січня); Вітоло все-таки загубив форму, коли грав за «Лас-Пальмас» (Ф1. - 2018. - 4 березня); Була задача пресингувати навіть при рахунку «два - нуль» (2+2. - 2018. - 18 березня); Олександр - вправний слюсар. Міг би робити на заводі аж до пенсії (СТБ. - 2018. - 26 березня); Звідти [з Австралії] попросили двох дипломатичних робітників, яких вважсють шпигунами (1+1. - 2018. - 27 березня); Родичі та знайомі розповсюдили інформацію з фотографіями чоловіків $(1+1 .-2018 .-10$ квітня); Ті зусилля, які прикладають гравиі «Тотенгема» (Ф1. - 2018. - 21 квітня); Наглядачі з Книги рекордів України стежать, щоб він не вставав (1+1. - 2018. - 21 червня); Виключенням є лише Томас Муні (I. - 2018. - 6 липня); Це дуже розповсюджена практика на довгих дистаниіях (УТ-1. - 2018. - 12 серпня); Такі дії можуть призвести до того, щоб знайти дірки в обороні суперника (НТА. - 2018. - 1 вересня); Збірна України потрапить на чемпіонат Свропи. Бронюйте білети (У. - 2018. - 6 вересня); Прямо

\footnotetext{
2 Пономарів, О. Д. (2000), Стилістика сучасної украӥнської мови: Підручник, Навчальна книга Богдан, Тернопіль, с.56.

3 Там само, с.59.

4 Зубков, М. Г. (2008), Практичний словник синонімів украӥнської мови, Весна, Харків, с. 4.
} 
ідеально потрапив по м’ячеві Маріш Ківерс (Ф1. - 2018. - 7 вересня); Подивитися на козла на прапорі - задача непроста (1+1. - 2018. - 28 вересня); Головна задача детектива - назбирати достатньо доказів (24. - 2018. - 1 жовтня); У разі ДТП пасажир з білетом все-таки застрахований (1+1. - 2018. - 30 жовтня); Сьогодні в українських музикантів непроста задача (Прм. - 2018. - 18 листопада); Ми купували білети на концерт Баскова, Кіркорова (Прм. - 2018. - 18 листопада); Полум'я швидко розповсюджувалося (Ec. - 2018. - 18 листопада); Його першочергова задача - відновити братські стосунки з Росією (24. - 2018. - 23 листопада); Що змінить військовий стан? (24. - 2018. - 27 листопада); Їх буквально за кілька хвилин можна переобладнати для виконання будь-яких задач (1+1. - 2018. - 10 грудня); Президент запропонував ввести військовий стан (24. - 2018. - 21 грудня).

Як правильно зауважила Г. Й. Волкотруб, «розбіжності у значенні спричиняють різну сполучуваність синонімів» ${ }^{5}$. Не можемо не додати до цієї виразно помітної закономірності ще й те, що не лише розбіжності у значенні спричиняють різну сполучуваність синонімів, а й розбіжності в експресивному й у стилістичному забарвленні. Яскравий приклад цього демонструють наведені тут цитати 3 прямоефірного мовлення телевізійних журналістів. Зокрема, якщо завдання і задача, розповсюджувати і поширювати, робітник і прачівник, загубити і втратити, прикладати і докладати, білети і квитки, військовий і воєнний ще мають якоюсь мірою часткову спільну сполучуваність, то робити і працювати, потрапити і влучити таких зв'язків із іншими компонентами контексту практично не мають.

Сплутування слів завдання і задача, розповсюджувати і поширювати, робити і працювати, робітник і працівник, загубити і втратити, прикладати і докладати, наглядачі і спостерігачі, виключення і виняток, білети і квитки, потрапити і влучити, військовий і воєнний свідчить не лише про обмежений словниковий запас і незнання синонімів, але й про вплив російської мови.

Проте є й ціла низка слів, які вживають тележурналісти у своєму мовленні наживо через брак знання такого самого українського слова-синоніма, адже в російській мові це слово позначає трохи інше поняття, має трохи інший відтінок у значенні, трохи по-іншому забарвлене експресивно, а инколи й узагалі нема такого слова в українській мові, а є зовсім інше. Ми виявили в прямоефірному мовленні тележурналістів за досліджуваний період 321 такий приклад. Наводимо найбільш типові випадки, уникаючи повторень однакових і однотипних цитат: Шахматний столик. За ним грав у шахмати Степан Бандера (24. - 2018. - 1 січня); Це є признаком того, шьо украӥнське кіно повертається (Ес. - 2018. - 1 січня); Це найстаріший жсилий замоку світі (Ec. - 2018. - 3 січня); Півтора роки назад Саша привезла з Украӥни свою розробку (1+1. - 2018. - 3 січня); Один з варіантів знайти гроші для держави - включити друкарський станок (112. - 2018. - 4 січня); Поклонська з мечем в руках вийде на тропу війни (24. - 2018. - 5 січня); Поруч жеде вокзал, інститут Прм. - 2018. - 5 січня); $\epsilon$ група з Німеччини, Руминії, Росії (112. - 2018. - 6 січня); Він на днях літав на Кариби (24. - 2018. - 7 січня); Три тижні Коутіньйо може пропустити через травму бедра (24. - 2018. - 8 січня); Червоні висипання на шкірі, гарячка та головний біль (ZIK. 2018. - 9 січня); Це написано поміж строк, так би мовити, пане Юрію (Прм. - 2018. -

5 Волкотруб, Г. Й. (2009), Практична стилістика украӥнської мови: Навчальний посібник, Підручники і посібники, Тернопіль, с. 59. 
9 січня); Причиною пожежі стали електричні прибори, якими обігрівались мешканці (Прм. - 2018. - 15 січня); Сума застави, яка в три рази менше за суму взятки (24. 2018. - 16 січня); Де піднімають членські взноси? (1+1. - 2018. - 21 січня); Сдиним джерелом світла була оия польська керосинова лампа (1+1. - 2018. - 21 січня); Автобус віз робочих на зміну (1+1. - 2018. - 24 січня); Зараз Матяш проходить просмотр в казахстанському «Алдайку» (Ф1. - 2018. - 24 січня); Вони були свідками його [Януковича] побігу до Росії (24. - 2018. - 25 січня); Його більше ичікавить мілка риба (24. - 2018. - 30 січня); Паралельно намагалася знайти нове призвання, пробувала себе в ролі проповідниці (24. - 2018. - 30 січня); Оце вхід в столову. Сюди привозили продукти (1+1. - 2018. - 5 лютого); НАБУ стала адвокатом біглого депутата Онищенка (Ес. - 2018. - 10 лютого); «Тесла» буде літати в безвоздушному просторі, а Сашко буде обурюватися (Обоз TV. - 2018. - 10 лютого); Правда заключається в тому, шьо Росія залишилася в світовому співтоваристві (Ec. - 2018. - 11 лютого); На думку авторів докладу, Росія збирається робити нові вибори у нас (1+1. - 2018. 14 лютого); Лишні кілограми у Мбокані присутні (Ф1. - 2018. - 15 лютого); Блондин. Крашений блондин (Ф2. - 2018. - 15 лютого); Прийшли ті кияни і некияни, які хотіли почтити пам'ять героїв Небесної Сотні (24. - 2018. - 18 лютого); Брати Райт ведуть переписку з іншими винахідниками (24. - 2018. - 23 лютого); Суддя боковий підняв флажок (2+2. - 2018. - 4 березня); Росіяни пристально стежать за тим, щуо відбувається в Сполучених Штатах (24. - 2018. - 12 березня); В нас досі працюють гральні заклади під видом лотерей [титр] (24. - 2018. - 15 березня); За виручені кошти придбають обладнання для реабілітаційного центру (Льв. - 2018. - 15 березня); Валерія Гонтарева там мала значну долю акцій (1+1. - 2018. - 18 березня); Приватні будинки засипало по вікна. Автівок не видно під сугробами (24. - 2018. - 19 березня); Дозвіл видало державне відомство із судоходства (1+1. - 2018. - 27 березня); Розведений президент не проблема, а от неодружений імператор - нонсенс (24. 2018. - 30 березня); Росія - країна дивних співпадінь (24. - 2018. - 3 квітня); Правда сьогодні наступна: правда полягає в тому, щзо «Барселону» вважають фаворитом матчу (Ф2. - 2018. - 4 квітня); Пушка насичує воду киснем (СТБ. - 2018. - 5 квітня); Саме сьогодні треба пекти великодні куличі (Прм. - 2018. - 6 квітня); С там розвалини римського театру. Красиве місто Малага (Ф2. - 2018. - 15 квітня); Весілля в шалаші молодята відгуляли (1+1. - 2018. - 20 квітня); Капітан сьогодні на висоті, навіть не дивлячись на результат (Ф1. - 2018. - 22 квітня); У них навіть перепонки на лапах є (1+1. - 2018. - 25 квітня); Низькопольний громадський транспорт [титр] (Льв. - 2018. - 27 квітня); Мають щче гривневі збереження готівкою та в банках (1+1. - 2018. - 29 квітня); Такий підйомник дозволяє без проблем піднятися, нажавши лише одну кнопку (ZIK. - 2018. - 1 травня); Цей епізод має надихати франиузів у першу чергу (НЛО. - 2018. - 3 травня); За двісті-триста метрів забор [військової частини] (1+1. - 2018. - 8 травня); У Гватемалі затримали історичний груз із трьома тоннами наркотиків, які перевозило судно під флагом Танзанії [титр] (Обоз TV. - 2018. - 9 травня); Це неправильні пчоли і в них неправильний мед (СТБ. - 2018. 10 травня); Франиузи і італьяниі мені подобаються навіть більше (СТБ. - 2018. 10 травня); Починаються дуже розвеселі качелі (СТБ. - 2018. - 12 травня); Брав він таку баснословну суму - п'ятдесят тисяч доларів (24. - 2018. - 17 травня); Там їм пообіияли ичей ричаг тиску на Кремль (24. - 2018. - 19 травня); Марокко знаходиться на південь від Свропи через Гібралтарський пролив (Ф1. - 2018. - 31 травня); Це все 
досужі домисли (24. - 2018. - 1 червня); Російські чиновники відреагували бурно (Ес. 2018. - 3 червня); Дуже швидко відреагував слідчии комітет РФ, прямо молнієносно (Ec. - 2018. - 3 червня); Ще одна річ, трохи не така забавна (Ec. - 2018. - 3 червня); Поки шо не змогли потушити пожежу, полетіли за водою (1+1. - 2018. - 5 червня)» В Вашингтоні не готові до чергової схватки з Брюсселем (24. - 2018. - 10 червня); Він забув поставити машину на ручний тормоз (I. - 2018. - 16 червня); Дуже спокійно до ивього відносяться захисники збірної Хорватії (I. - 2018. - 21 червня); До сих пір рахунок так і залишається нічийним (I. - 2018. - 22 червня): Жодних сумнівів у його пригодності навіть у такому поважному футбольному віці! (I. - 2018. - 22 червня); Ти, як бабушка, розсуждаєш (Обоз TV. - 2018. - 28 червня); Про приюти більше казав Кіліян Мбаппе (I. - 2018. - 30 червня); Це традиційна команда з Словакії (Льв. 2018. - 13 липня); Агітатори, плакати, наружна реклама? (1+1. - 2018. - 18 липня); Ви знаходилися вдома, коли завалилася криша? (ZIK. - 2018. - 23 липня); На тому участку, клаптику поля йшла боротьба (ZIK. - 2018. - 12 серпня); За заказом колишнього кандидата в президенти він взяв гроші (1+1. - 2018. - 22 серпня); Росія, Туриія та Іран братимуть участь у створенні нової конституиії Сирії [титр] (Обоз TV. - 2018. - 25 серпня); Тут вже колокола футбольні б’ють на всю Бесарабку (Ф1. 2018. - 28 серпня); Атомна підводна лодка «Курськ». Саме тут ї збудували (СТБ. 2018. - 29 серпня); Як частна особа приїде і Президент Украӥни Петро Порошенко (1+1. - 2018. - 31 серпня); Гості мають відповідати на питання - гострі питання, невдобні питання (Прм. - 2018. - 3 вересня); Сьогодні Сполучені Штати являються найпотужнішим партнером України у світі (СТБ. - 2018. - 12 вересня); За діючим законодавством забудовники нікому нічого не зобов'язані (24Л. - 2018. - 14 вересня); Вони діляться рецептами блюд (1+1. - 2018. - 22 вересня); Цілком можливо, иче була пробка від бутилки (Ф1. - 2018. - 30 вересня); Вони просто йдуть і роблять вигляд, щзо журналісти - назойливі мухи (24. - 2018. - 2 жовтня); Наступне засідання відбудеться за дві неділі-шістнадиятого жовтня (1+1. - 2018. - 2 жовтня); Люди побачили зарево, люди побачили вогняний гриб на горизонті (1+1. - 2018. - 9 жовтня); Технічну воду можна взяти ось тут, на пруду (1+1. - 2018. - 16 жовтня); Якщо тут проїжджатиме велосипедист і автомобіліст з такою скорістю, станеться аварія (24. - 2018. - 1 листопада); Чи можна такими резиновими виробами пробити голову? (1+1. - 2018. - 2 грудня); Допомагати вважає своїм боргом (2+2. - 2018. - 12 грудня); У яких країнах наших співвітчизників чекають з розпростертими обіймами? (24. - 2018. - 18 грудня).

Слова і вислови телевізійних журналістів, вжиті в мовленні наживо, мають прямі відповідники в українській мові: шахмати - шахи, признак - ознака, жилий житловий, назад - тому, включити друкарський станок - увімкнути друкарський верстат, тропа війни - стежка війни, жеде вокзал - залізничний вокзал, Руминія, Словакія, Турція - Румунія, Словаччина, Туреччина, на днях - цими днями, бедро - стегно, гарячка - лихоманка, поміж строк - поміж рядків, електричні прибори - електричні прилади, взятка - хабар, взноси - внески, керосинова лампа - гасова лампа, робочий - робітник, просмотр - перегляд, побіг - втеча, біглий - втікач, мілка риба - дрібна риба, призвання - покликання, столова - їдальня, воздух - повітря, заключається - полягає, доклад - доповідь, лишній - зайвий, крашений - фарбований, почтити - вшанувати, переписка - листування, флажок, флаг - прапорець, прапор, пристально - пильно, під видом - під виглядом, виручені кошти - вторговані 
кошти, доля - частка, сугроби - замети, судоходство - судноплавство, розведений розлучений, співпадіння - збіг, правда сьогодні наступна - правда сьогодні така, пушка - гармата, куличі - паски, розвалини - руїни, шалаш - курінь, не дивлячись на результат - не зважаючи на результат, перепонки на лапах - перетинки на лапах, низькопольний громадський транспорт - низькопідлоговий громадський транспорт, збереження - заощадження, нажати - натиснути, у першу чергу - насамперед, забор - паркан, груз - вантаж, пчоли - бджоли, італьянці - італійці, качелі - гойдалки, баснословний - неймовірний, ричаг - важіль, пролив - протока, досуг - дозвілля, досужі - пусті (марні), бурно - бурхливо, молнієносно - блискавично, забавний - кумедний, потушити пожежу - погасити пожежу, схватка - сутичка, тормоз - гальмо, відносяться - ставляться, до сих пір - досі, пригодність - придатність, розсуждаєш розмірковуєш, наружний - зовнішній, криша - дах, участок - ділянка, заказ - замовлення, колокол - дзвін, лодка - човен, частний - приватний, невдобні питання - незручні питання, являються - $\epsilon$, діюче законодавство - чинне законодавство, рецепти блюд - рецепти страв, бутилка - пляшка, назойливі мухи - набридливі мухи, за дві неділі - за два тижні, зарево - заграва, пруд - ставок, скорість - швидкість, резиновий - гумовий, вважає своїм боргом - вважає своїм обов'язком, з розпростертими обіймами -з розкритими обіймами. На перший погляд здається, що єдина можливість не зауважити цього - це не знати слова-синоніма чи взагалі українського слова (на відміну від російського). Проте тут не все так однозначно, адже мовлення відбувається в прямому ефірі. Журналіст не має змоги довго роздумувати над кожним словом, зважувати його стилістичне чи експресивне забарвлення, а то й відтінки в значенні. Найточніше може висловити свою думку в цьому разі лише той мовник, для якого природною мовою поза ефіром є українська. Тому часто в мовленні наживо зринають у пам'яті насамперед ті слова, які звик репортер уживати на позначення певних понять. Часу для роздумів обмаль, а над «синонімами» цих слів треба ще подумати. Слово «синоніми» тут ми взяли в лапки, бо часто це тільки у миттєвому сприйнятті тележурналіста під час мовлення наживо згадані лексеми є синонімами. Насправді ж це просто слова з різних мов або й міжмовні омоніми. Тут можна порекомендувати скористатися «Російсько-українським словником синонімів» ${ }^{6}$. Наприклад, вжите вище помилково в прямому ефірі російське «бабушка (мать отца или матери)» перекладають українськими словами «бабуся, бабуня» 3 позначкою пестл.

Є й випадки, відверто близькі до міжмовних омонімів: Будете допомагати нам розбиратися у величезній купі інформації (Ec. - 2018. - 9 червня). Звісно, не можна говорити, що слово «розбиратися» в сучасній українській мові вживають лише як синонім до слова «роздягатися», проте й до цього слова в наведеному тут значенні $€$ низка синонімів: розумітися, розглядати та ін. А в деяких випадках ідеться справді про міжмовні омоніми: Будинок із дурною [треба «поганою»] славою Багряний перейменував із «Слово» у «Крематорій» (24. - 2018. - 20 травня); Вони можуть залишити [треба «позбавити»] ї̈ права голосу (24. - 2018. - 27 червня); Ці докази знайшли робітники [треба «працівники»] Центрального архіву громадських об'єднань (1+1. 2018. - 19 листопада); Вони пробули в морі двадцять днів і майже лишилися надії

6 Пилинський, М. М. (Ред.) (1995), Російсько-украӥнський словник синонімів, Освіта, Київ, 265 с.

7 Там само, с. 9. 
[треба «втратили надію»] на порятунок (Ec. - 2018. - 24 грудня). Ми так само можемо порекомендувати найпростіший вихід: у разі будь-яких сумнівів такого плану звертатися до «Словника російсько-українських міжмовних омонімів» М. П. Кочергана ${ }^{8}$. Наприклад, російське «дурной» («плохой, скверный по качеству») перекладається тут як «укр. поганий, недобрий» ${ }^{9}$, а не «дурний»; російське «лишить» (отнять что-либо у кого-либо) перекладається як «укр. позбавити, відібрати» ${ }^{10}$, а не «залишити, лишити»; російське «работник» («тот, кто занимается какой-либо работой или профессией») перекладається як «укр. працівник» ${ }^{11}$, а не «робітник» і т. ін.

Часто внаслідок незнання синоніма виникає тавтологія. Всього ми проаналізували 143 виявлені приклади. Наводимо найбільш характерні з них: Відбувся суд у Київському апеляційному суді (Ес. - 2018. - 3 січня); Вони планували плани своєї адміністраиії на наступний рік (НТА. - 2018. - 8 січня); Корабель м'яко приземлився на Землю (СТБ. - 2018. - 12 січня); Продовжують праџюювати установи, які працююють в галузі держбезпеки (24. - 2018. - 20 січня); Організатори хочуть організувати так, шуоб кожен висловився (5-й. - 2018. - 22 січня); Захід охороняли посилені кордони правоохоронців (1+1. - 2018. - 2 лютого); Бетховен створив безліч творів (24. - 2018. - 6 лютого); Працівники прац̧юють. Поруч них стоять працівники правоохоронних органів (Ес. - 2018. - 13 лютого); У ичей день всі одягали традиційний одяг (Ес. - 2018. - 17 лютого); Дотримання режиму тиші бойовики не дотрималися (5-й. - 2018. - 22 лютого); Будуть розглядати матеріали слідства, які зібрало слідство (24. - 2018. - 27 лютого); Садити саджанці в землю поки що не варто (Льв. - 2018. - 1 березня); Участь у ньому взяли сімнадиять учасників (Льв. - 2018. 9 березня); До Верховної Ради подали подання про арешт (24. - 2018. - 15 березня); Вона пішла на першу вільну вакансію в балетне училище (1+1. - 2018. - 18 березня); Столична багатоповерхівка в спальному районі столиці здригнулась від вибуху (ZIК. - 2018. - 19 березня); Цей прилад можна використовувати у всіх галузях, де використовують автоматику (Льв. - 2018. - 21 березня); Я не буду називати назву (Ec. - 2018. - 24 березня); Виплати, які зобов'язалася держава виплачувати $(1+1$. - 2018. - 29 березня); Ракетний комплекс «Вільха» українського виробництва має бути вже ичього року у виробництві (5-й. - 2018. - 25 квітня); Ця команда викликає дуже добрі симпатії (2+2. - 2018. - 6 травня); У додатку можна додати свою скаргу (24Л. - 2018. - 10 травня); Еміне Джапарова наводить, наприклад, такий приклад (24. - 2018. - 18 травня); Не думаю, щзоб думали про атаку в останні секунди для них (I. - 2018. - 15 червня); Складність полягає ще й в тому, щчо у Конго дуже складний рельєф місиевості (24. - 2018. - 16 червня); Він з «Реалом» не здобув ніяких здобутків, нічого не виграв (I. - 2018. - 20 червня); Його старма донька навчається у тому ж навчальному закладі $(1+1 .-2018 .-23$ червня); $C$ змішувачі які змішують (24Л. - 2018. - 25 червня); Діти, які були поруч із постраждалим хлопцем, не постраждали (1+1. - 2018. - 11 липня); Мінімум три м'ячі в матчі за третє місие мали місие (I. - 2018. - 14 липня); Не можу тебе не спитати таке питання (Ес. 2018. - 1 вересня); Останні хвилини. Можливо, щуе десять буде, якщо додані додати

\footnotetext{
8 Кочерган, М. П. (1997), Словник украӥнсько-російських міжмовних омонімів (“фальшиві друзі перекладача"), Академія, Київ, 400 с.

9 Там само, с. 128.

10 Там само, с. 189.

${ }^{11}$ Там само, с. 275.
} 
(НТА. - 2018. - 1 вересня); Його виконуватиме перший виконавеиьь (24Л. - 2018. 4 жовтня); Така ситуачія триває в клубі вже тривалий час (Ф2. - 2018. - 8 жовтня); Треба посилити зусилля (СТБ. - 2018. - 1 листопада); Поряд світиться світло (24. - 2018. - 3 листопада); На даний момент без моментів фактично грають україниі (Ф1. - 2018. - 17 листопада); Тут уже виставлена виставка про подї революиї (1+1. - 2018. - 22 листопада); Мешканиі скаржаться на забудовника, який на тій вуличі будує будинок (Льв. - 2018. - 22 листопада); Треба сказати про групу підтримки, яка прийшла підтримати затриманих (1+1. - 2018. - 30 листопада); Намі очільники скористаються ииим на користь Украӥні (1+1. - 2018. - 2 грудня); Найдовший паркан розписаний петриківським розписом (Ес. - 2018. - 4 грудня); Обоє успадкували дивний спадок від батька (24. - 2018. - 13 грудня); Сніжні насипи лише посипали зверху піскосумішшю (ПЗ. - 2018. - 18 грудня); Фактично початок робіт почнеться пізніше (Ес. - 2018. - 30 грудня).

Майже всі цитати 3 мовлення наживо, наведені тут, засвідчують збіднену мову репортерів, ведучих випусків новин та спортивних коментаторів. Досить легко в спокійних умовах 3 використанням словників синонімів ${ }^{12}$ знайти відповідне слово на заміну однокореневому, яке пролунало в прямому ефірі: «вони планували плани» - «вони складали плани», «м'яко приземлився на Землю» - «м’яко сів на Землю», «організатори хочуть організувати так» - «організатори хочуть зробити так» тощо. Найбільш прикрою є тавтологія в титрах: На конкурсі Соломію нагородили двома нагородами [титр] (24Л. - 2018. - 29 травня). І тут легко замінити «нагородили» на «вручили». Титри мають бути максимально лаконічними й змістовними, проте цейтнот під час випусків новин, окремим компонентом яких часто $€$ коротке інтерв’ю 3 гостем студії, позначається инколи й на написах та підписах, на рухомому рядку.

Дослідивши різні аспекти використання стилістичних синонімів у телевізійному мовленні наживо, ми дійшли таких висновків:

1. Використання всього лексичного багатства української мови під час мовлення в прямому ефірі, а не обмеженість лексикону телевізійних «персонажів» кількома десятками модних слів. Таке просте й водночас поки що недосяжне завдання постає перед сучасними телевізійниками із запровадженням мовних квот в ефірі.

2. Найбільш характерним є вживання одних слів із синонімічного ряду замість інших без урахування відтінків у значенні й у емоційному чи стилістичному забарвленні. Не лише розбіжності у значенні спричиняють різну сполучуваність синонімів, а й розбіжності в передаванні різних експресивних і стилістичних відтінків.

3. Сплутування слів під час мовлення наживо часто свідчить не лише про обмежений словниковий запас тележурналістів і незнання синонімів, але й про вплив російської мови. $€$ ціла низка слів, які вживають тележурналісти у своєму мовленні наживо через брак знання такого самого українського слова-синоніма, адже в російській мові це слово позначає трохи інше поняття, має трохи інший відтінок у значенні, трохи по-іншому забарвлене експресивно, а инколи й узагалі нема такого слова в українській мові, а $є$ зовсім інше.

12 Див.: Зубков, М. Г. (2008), Практичний словник синонімів української мови, Весна, Харків, 720 с.; Караванський, С. (1993), Практичний словник синонімів украйнської мови, Орій, Київ, 472 с.; Полюга, Л. М. (2001), Словник синонімів украӥнської мови, Довіра, Київ, 477 с.; Бурячок, А. А., Гнатюк, Г. М. та Головащук, С. І. (Ред.) (1999-2000), Словник синонімів украйнської мови: В 2 m., Наукова думка, Київ, т. 1-2. 
4. Часто слова і вислови телевізійних журналістів, вжиті в мовленні наживо, мають прямі відповідники в українській мові. На перший погляд здається, що єдина можливість не зауважити цього - це не знати слова-синоніма чи взагалі українського слова (на відміну від російського). Проте тут не все так однозначно, адже мовлення відбувається в прямому ефірі. Журналіст не має змоги довго роздумувати над кожним словом, зважувати його стилістичне чи експресивне забарвлення, а то й відтінки в значенні. Найбільш точно може висловити свою думку в цьому разі лише той мовник, для якого природною мовою поза ефіром є українська. Тому часто в мовленні наживо зринають у пам'яті насамперед ті слова, які звик репортер уживати на позначення певних понять. Часу для роздумів обмаль, а над «синонімами» цих слів треба ще подумати. Подеколи тільки у миттєвому сприйнятті тележурналіста під час мовлення наживо згадані лексеми є синонімами. Насправді ж це просто слова 3 різних мов або міжмовні омоніми.

5. Часто внаслідок незнання синоніма виникає тавтологія, що засвідчує збідненість мови репортерів, ведучих випусків новин та спортивних коментаторів.

Постійна праця над удосконаленням свого мовлення полягає насамперед у збагаченні словникового запасу журналістів, а отже, у використанні всього синонімічного багатства української лексики. У подальших дослідженнях розглянутих тут питань варто зосередити увагу на з'ясуванні психологічних аспектів хибного використання лексичних синонімів у телевізійному мовленні наживо.

\section{СПИСОК ЛІТЕРАТУРИ}

1. Волкотруб, Г. Й. (2009), Практична стилістика украӥнської мови: Навчальний посібник, Підручники і посібники, Тернопіль, 256 с.

2. Зубков, М. Г. (2008), Практичний словник синонімів украӥнської мови, Весна, Харків, $720 \mathrm{c.}$

3. Караванський, С. (1993), Практичний словник синонімів украӥнської мови, Орій, Київ, 472 с.

4. Кочерган, М. П. (1997), Словник українсько-російських міжмовних омонімів (“фальшиві друзі перекладача”), Академія, Київ, 400 с.

5. Полюга, Л. М. (2001), Словник синонімів украӥнської мови, Довіра, Київ, 477 с.

6. Пономарів, О. Д. (2000), Стилістика сучасної украӥнської мови: Підручник, Навчальна книга - Богдан, Тернопіль, 248 с.

7. Пилинський, М. М. (Ред.) (1995), Російсько-украӥнський словник синонімів, Освіта, Київ, 265 с.

8. Бурячок, А. А., Гнатюк, Г. М. та Головащук, С. I. (Ред.) (1999-2000), Словник синонімів украӥнської мови: В 2 т., Наукова думка, Київ, т. 1-2.

\section{REFERENCES}

1. Volkotrub, H. J. (2009), Practical Stylistic of Ukrainian: Manual, Pidruchnyky i Posibnyky, Ternopil, $256 \mathrm{p}$.

2. Zubkov, M. H. (2008), Practical Dictionary of Ukrainian synonyms, Vesna, Kharkiv, 720 p.

3. Karavanskyi, S. (1993), Practical Dictionary of Ukrainian synonyms, Oriy, Kyiv, 472 p. 
4. Kocherhan, M. P. (1997), Dictionary of Ukrainian \& Russian Interlingual homonyms ("False Friends of Translator"), Academia, Kyiv, 400 p.

5. Poliuha, L. M. (2001), Dictionary of Ukrainian synonyms, Dovira, Kyiv, 477 p.

6. Ponomariv, O. D. (2000), Stylistic of Modern Ukrainian: Text-book, Pidruchnyky i Posibnyky, Ternopil, $248 \mathrm{p}$

7. Pylynskyi, M. M. (Ed.) (1995), Russian \& Ukrainian Dictionary of synonyms, Osvita, Kyiv, $265 \mathrm{p}$.

8. Buriachok, A. A., Hnatiuk, H.M. \& Holovashchuk, S.I. (Ed.) (1999-2000), Dictionary of Ukrainian synonyms: In 2 vol., Naukova dumka, Kyiv, vol. 1-2.

\title{
STYLISTIC SYNONYMS IN TELEVISION LIVE SPEECH
}

\author{
Anatolyi Kapelyushnyi \\ Ivan Franko National University of Lviv, \\ Generala Chuprynky Str. 49, 79044, Lviv, Ukraine \\ e-mail: journft@franko.lviv.ua \\ https://orcid.org/0000-0001-8998-7857
}

The article analyzes the stylistic synonyms in TV live broadcast live. This is main objective of the study. Methodology of the study foreordain using for study observation, comparison, analysis, synthesis, generalization. Particular attention is drawn to the use of some words from the synonymic series instead of the others without taking into account the shades in meaning and in emotional or stylistic colors, differences in meaning and in expressive and stylistic colors that cause different connectivity of synonyms, mistakes in the broadcasting of television journalists, the lack of compliance with language, stylistic and linguistic norms, ways to avoid these mistakes, and the development of appropriate recommendations for TV journalists. Having examined various aspects of the use of stylistic synonyms in live television speech, we came to some following conclusions. The mix up of words in live speech often proves not only the limited vocabulary of TV journalists and ignorance of synonyms, but also the influence of the Russian language. There are a number of words that journalists use in their speech live because of the lack of knowledge of the same Ukrainian word synonym, because in the Russian language this word means a slightly different concept, has a slightly different tint in meaning, is slightly differently colored expressively, and sometimes there is generally no such word in the Ukrainian language, but there is a completely different one. Often the words and phrases used by television journalists in live broadcast have equivalents in the Ukrainian language. But broadcasting is broadcast live. A journalist can not think for a long time every word, weigh its stylistic or expressive color, or even shades of meaning. Most likely, one can express his opinion in this case only to the broadcaster, for whom the natural language is outside of the ether is Ukrainian. Constant work on improving their speeches is, first of all, in enriching the vocabulary of journalists, and hence the use of all synonymous luxuriance of Ukrainian vocabulary. In further research, the issues discussed here should focus on clarifying the psychological aspects of the misuse of lexical synonyms in live television speeches.

Key words: television, live broadcast, television journalist, broadcasts of television journalists, stylistic synonyms, connectivity of synonyms. 